\title{
Board Meeting Attendance by Outside Directors
}

\author{
Byung S. Min and Amon Chizema
}

Outside directors' regular board meeting attendance is important in improving the effectiveness of a governance system. Such attendance is evidence of their commitment to the firm as key other players in monitoring and decision-making. Using a unique dataset for Korean firms, and three-level random coefficients models, we find that, foreign outside directors, an independent appointment process, professional knowledge of business operations, and accumulated firm-specific knowledge are important factors that affect outside directors' attendance of board meetings. The results also confirm that both outside directors' personal characteristics and the social context are crucial in understanding their board meeting attendance. Further analysis shows that a positive corporate environment that supports the outside director system encourages outside directors' attendance at board meetings.

Key words: Board meeting; outside directors; corporate governance; organizational commitment; Korea 


\section{INTRODUCTION}

A growing stream of corporate governance literature treats the frequency of board meetings as a measure of outside directors' involvement (Brick and Chidambaran, 2010; Ntim and Osei, 2011) and commitment to monitor top management (Adams, 2005; Cai, Garner and Walkling, 2009). As such the number of meetings has been used as a proxy for active boards (Carter, Simkins and Simpson, 2003; Xie, Davidson and DaDalt, 2003), board diligence (Carcello, Hermanson and Neal, 2002) and considered, too, as an important factor in improving board effectiveness (Conger, Finegold and Lawler III, 1998). The number of board meetings has also been found to be inversely related to firm value (Vafeas, 1999), suggesting that firms react to poor performance by increasing the frequency of board meetings.

Generally, meetings are planned gatherings of three or more people who assemble for a purpose that is ostensibly related to some aspect of organizational or group function (Boden, 1995; Schwartzman, 1989). In the context of the corporation, board meetings are the primary mechanism for outside directors to keep informed of a firm's operations (Masulis, Wang and Xie, 2012), business conditions and managerial decision making (Adams and Ferreira, 2008), so that they can effectively participate in a firm's governance (Lipton and Lorsch, 1992). Consequently, institutional investors and governance activists have used board meeting attendance records to evaluate director performance, and directors who frequently miss board meetings are often criticized as being ineffective monitors and receive significantly fewer votes for their re-election (Cai et al., 2009).

Board meetings have also been a subject of interest in strategy research. For example, early empirical studies of strategy development such as that by Mintzberg (1973) demonstrated that managers spend more than 70 per cent of their time in discussion in different forms of meetings. More recently, scholars have studied meetings as a central arena for decision-making and strategizing by focusing on social processes within them and how 
they affect attention given to strategic issues (Jarzabkowski and Seidl, 2008). Attempts have also been made to understand how board directors and managers skilfully and dynamically interact with one another, through conversation, using goal-directed practices to achieve particular outcomes (Kwon, Clarke and Wodak, 2014).

Thus, we know about the importance of board meetings and the frequency at which they take place in firms and, to some extent, about the effects of meetings upon the organizations in which they take place (Jarzabkowski and Seidl, 2008). For example, Liu, Wang and Wu (2014) studied the effect of independent directors' attendance at board meetings on the tunneling behavior of large shareholders and found that a higher rate of independent director attendance protects investors by alleviating tunneling.

What we know less about is the behaviour of the actors [outside directors] concerning attendance at board meetings. This alludes to the lack of understanding of the factors that promote or undermine outside directors' attendance of board meetings. What motivates outside directors to attend board meetings? Does it take certain firm conditions and/or director characteristics to attend board meetings? In the context of Korea, our paper directly addresses this gap in understanding by drawing on insights from organizational commitment literature and theory (Mowday, Porter and Steers, 1982).

The choice of examining board meeting attendance by outside directors through the lens of organizational commitment, and of using Korea as a research laboratory, is justifiable. First, we argue that by accepting appointment, the outside director chooses to identify with and commits to help the firm achieve its strategic goals (Guth and MacMillan, 1986) by being present in the meetings where discussions and decisions about the firm take place. Attending meetings by outside directors, like turning up for work by employees, is manifestation of organizational commitment (Mathieu and Zajac, 1990). Second, Korea experienced dramatic 
changes in her corporate governance system, following the Asian financial crisis of 1997. Prior to the corporate governance reforms, controlling shareholders expropriated firm resources even when their ownership concentration was small (Chizema and Kim, 2010). Firms with a high disparity between control rights and ownership rights showed low profitability. When a business group transferred resources from a subsidiary to another, they were often wasted, suggesting that tunneling occurred. One of the mechanisms that were adopted to mitigate these governance problems is the use of outside directors. Yet we now know that attendance of meetings by outside directors reduces the likelihood of tunnelling, (Liu et al., 2014). Thus, understanding the determinants of this practice in a context like Korea (with a previous history of tunneling) is necessary.

When compared with reforms in the Anglo-American model, the use of outside directors in South Korea is relatively a recent innovation that was directly triggered by the financial crisis as discussed above. Yet, South Korea, having adopted the outside director system in 1998, could be considered as a leader in this respect when the sample of countries is restricted to Asia. For that reason, understanding the behavior of outside directors in South Korea could help other countries in the region, such as Japan, that are still contesting the idea of appointing outside directors (Chizema and Shinozawa, 2012).

Our study makes a number of contributions to the theory and literature of corporate governance. First, we view attendance of board meetings by outside directors as commitment to the goals and values of the firm. In the face of extensive criticism of the board and questions about the effectiveness of outside directors in controlling the CEO, this study opens a new avenue of examining outside directors through the lens of organizational commitment.

Second, in the context of Korea, Chizema and Kim (2010) examined the determinants of appointing outside directors. From their study, we know that a number of factors (foreign 
ownership, business group affiliation, weak financial performance) are associated with the appointment of outside directors. Chang, Oh, Park and Jang (2015) reported the importance of characteristics of board members on corporate social responsibility without addressing the reasons why board members attend board meeting. Min and Verhoeven (2013) reported a positive effect of outside director on firm value using characteristics of outside directors as instrument for the estimation. Apart from that we do not know what these outside directors in Korea actually do to help their firms. As a first step, they have to be where firm decisions are taken i.e. the boardroom. Our study builds on these previous ones by considering the behaviour of the directors at attending meetings, an initial step towards the board process.

Our estimations show that both outside directors' personal characteristics and the social context are crucial in understanding outside directors' board meeting attendance. Foreign outside directors, an independent appointment process, professional knowledge about business operations and accumulated firm-specific knowledge are identified as significant. By contrast, general experience - indicated by age and level of education - is not significant.

\section{THEORY AND HYPOTHESES}

\section{Organizational Commitment}

Organizational commitment may be defined as the relative strength of an individual's identification with and involvement in a particular organization (Mowday, Porter and Steers, 1982). It can be identified by at least three factors: (1) a strong belief in and acceptance of the organization's goals and values; (2) a willingness to exert considerable effort on behalf of the organization; and (3) a strong desire to maintain membership in the organization (Porter, Steers, Mowday and Boulian, 1974). Organizational commitment, therefore, derives from a desire to see the organization succeed in its goals and a feeling of pride at being part of the 
organization (Cohen, 2003), manifest in the individual's pledging or binding to certain behavioural acts (Salancik, 1977).

Further antecedents to commitment include the nature and quality of an employees' work and organizational experiences (Buchanan, 1974; Meyer et al., 2002). Moreover, commitment has been shown to be related to social involvement with colleagues (Sheldon, 1971), personal investments as length of organizational service, age (Hrebiniak, 1974), opportunities for achievement (Lee, 1971) and education (Koch and Steers, 1976). Of interest to this study, too, is that top management commitment has been seen as essential to the survival and health of complex organizations (Perrow, 1986; Selznick, 1957).

Previous research has also explored the consequences of organizational commitment (Steers, 1977). For example, highly committed employees should have a strong desire and intent to remain with the organization, an outcome implicit in the definition of commitment. Such behavioural intentions should be manifested in subsequent employee retention or turnover (Porter, et al., 1974) and absenteeism or attendance (Mathieu and Zajac, 1990; Meyer et al., 2002). Of course, commitment has also been seen to be related to performance under the assumption that committed employees would expend greater effort on the job.

Although these studies relate predominantly to the behaviour of employees, a lot can be drawn from them in order to improve our understanding of board meeting attendance by outside directors. We argue that outside directors are quasi-employees of the organization, rewarded for their services through director fees (Yermack, 2004) and punishable for their actions through non-re-election (Cai et al., 2009) and loss of reputation (Fich and Shivdasani, 2006). Indeed, corporate governance literature treats outside directors as individuals recruited to carry out two principal functions: monitoring and advising the board (Hermalin and Weisbach, 2006; Adams and Ferreira, 2008). We argue further that, consistent with previous studies, we view board meeting attendance as a measure of board involvement in the firm 
(Brick and Chidambaran, 2010; Vafeas, 1999) and as manifestation or an outcome of commitment (Meyer et al., 2002) by outside directors. Thus, in line with the three factors of commitment (Porter, et al., 1974), we posit that, first, attendance of meetings by outside directors signals a strong belief in and acceptance of the firm's goals and values. Second, in the case of outside directors, one can only exert considerable effort on behalf of the organization by attending the meeting in the first place. Specifically, directors can contribute to organizational goals only when they are present at work i.e. attend board meetings. Indeed, contributing to decision making is certainly an important director role, but concerns about contributions presuppose that directors are present at the board meetings. Third, for outside directors, a strong desire to maintain membership in the organization is demonstrated by socialising with other organizational actors in various forums including especially board meetings.

However, personal director circumstances or/and the organizational environment may hinder or encourage commitment by the outside director, consequently determining the level of board meeting attendance. Thus drawing on organizational commitment arguments we examine the determinants of board meeting attendance in a unique institutional context i.e. Korea. In the sections below, we develop our hypotheses.

\section{Foreign Outside Directors}

Earlier studies on Korean boards document an increasing trend of foreign outside directors (Chizema and Kim, 2010; Choi, Park and Yoo, 2007; Min, 2013; Min and Smyth, 2014). This is a natural outcome of the policy reforms in Korea focusing on the introduction of outside director system as one of main reforms, which is similar to other emerging markets (Reed, 2002). A firm may favour the appointment of foreign outside directors for some reasons. For example, foreign outside directors may be a more effective way of ensuring 
board independence. They may have special skills that, for example, allow them better access to the global capital market than local board members. Foreign outside directors may also have experience with the outside director systems in their home countries. Alternatively, a firm may favour the appointment of foreign directors mainly for promotional purposes, because it makes the board structure "look" better. However, we argue that most of these benefits would accrue to the firm where outside directors attend meetings to engage with other local directors in the business of monitoring and providing advice. But, such attendance is not guaranteed.

We suggest a number of reasons why foreign outside directors' may not attend board meetings. First, a director's geographic distance from corporate headquarters may prohibit on-site visits and attending board meetings (usually held at corporate headquarters) as this may become more difficult and time-consuming. Of course, from the commitment perspective, this undermines a director's ability and incentives to gather information and closely monitor management. Consistent with this view, Lerner (1995) finds that venture capitalists are reluctant to sit on boards of geographically distant firms, and Knyazeva, Knyazeva and Masulis (2011) document a significant local component to the matching process of companies and outside director candidates. The obstacles created by distance are even greater for foreign directors, as the time zone differences and time and energy consumed by international travel, coupled with heightened security concerns post 9/11 (Masulis et al., 2012), are likely to impose heavier burdens on foreign directors than on domestic directors, further eroding their commitment to attend meetings.

Second, cultural differences can be one barrier (Hofstede 1997). For example, in the Asian culture people tend to devote more time, than Westerners, greeting each other before 
discussing the main issues of the meeting. This may reflect different views on the value of time and on establishing relationships (Ebrey, Walthall and Palais, 2009).

Third, a foreign outside director may also face disadvantages in communicating in the local language, potentially getting discouraged from attending meetings. Communication in English is a challenging task in Korea. Most non-Korean outside directors rely on English to communicate at board meetings, without an English interpreter. Almost all documents for board meetings are in Korean, and normally board members are expected to read relevant materials before attending meetings, and to study the issues to be discussed during the meeting. Moreover, as board members, outside directors need to be able to listen to and debate other people's viewpoints. Because of these oral and written communication difficulties (Gilsdorf, 1986; Ebrey, Walthall and Palais, 2009), we expect non-Korean directors to have less motivation to attend board meetings. Furthermore, foreign outside directors may have difficulties because of their absent or weak informal social networks and different understandings of the meeting process due partly to cultural differences. Therefore, we hypothesize:

H1. Foreign outside directors will attend board meetings less frequently than local outside directors.

\section{Outside Directors Appointed through an Independent Screening Process}

Independent and affiliate directors are both subsets of outside directors. The former refers to a group of directors that has no past dealings with the firm, while the latter could be former employees or executive directors of the focal firm (Rediker and Seth, 1995). They could be even friends or relations of the CEO. Studies show that independent directors are better for company boards (Fama and Jensen, 1983; Min and Verhoeven, 2013; Choi et al., 2007; 
Black, Jang and Kim, 2006). Consequently, some companies appoint a good proportion of independent directors. One strategy to ensure that the right people are appointed to the board is to apply an independent screening process through an appropriate nomination committee (Kim and Lee, 2015). From several possible reasons why outside directors appointed through an independent screening process are likely to be more committed to the cause of the organization, we discuss two below. First, outside directors appointed through an independent screening process tend to have a stronger sense of self-regulation and desire to establish a good reputation because their reputation represents their marketability in the outsider market. Outsiders who are concerned with their reputation will exercise less ex post opportunism after their appointment and/or have more motivation to advertise themselves through regular attendance at the board meetings (Nelson 1974; Spence 1973). Second, they are not beholden to the CEO for their appointment, and thus attend meetings without conflict of interest. Such confidence and commitment to the firm and not to the CEO should result in better meeting attendance.

H2. An outside director appointed through an independent selection process will attend board meetings more frequently than others.

\section{Re-appointed Directors}

For the director, reappointment to the board is a reflection of good reputation and marks an extension to professional tenure ( $\mathrm{Lu}$ and Sun, 2010). Such a director is likely to pay more attention to job performance as poor performance will dramatically impair his or her reputational capital. Relatedly, Vafeas (2003) argues that directors who survive long tenure must perform well if the job market of directors is efficient. Moreover, previous studies (e.g., Salancik, 1977; O’Reilly and Caldwell, 1981) suggest that directors' organizational commitment increases in tenure. Indeed, Salancik (1977) argues that people’s actions become 
more committing if the revocability of their actions is lower. Furthermore, O'Reilly and Caldwell (1981) provide evidence that behavioural commitment is significantly associated with lower job turnover. We argue that directors' re-appointment to the board signifies the trust and level of satisfaction that shareholders have in the individuals. This act is, on the part of the director, is reassuring and translates into role satisfaction, an aspect that should enhance re-appointed directors' commitment to fulfil their duties, including the attendance of board meetings. This argument draws support from the social exchange approach to commitment, which makes the general proposition that people feel bound to an entity to the extent that it is associated with positive experiences for them (Mowday et al., 1982).

In summary, re-appointed directors have greater experience, expertise, reputation and reassurance, at least, with the focal firm, thus garnering confidence to meet more regularly with other directors to discuss the business of the firm.

H3: Reappointed outside directors are more likely to attend board meetings more regularly than newly appointed ones.

\section{Busy Directors}

The issue of busy directors has often been seen in terms of the number of board seats that an individual director holds (Fich and Shivdasani, 2006). Corporate governance scholars do not agree on the issue of busy directors i.e. directors who hold multiple board seats. One view is that multiple board seats indicate the importance of the director-hugely sought after by several firms. By engaging with several companies, such directors have extensive access to knowledge and acquire useful experience that, potentially, helps all the companies in the network. Given this background, such directors, we argue, are confident and would commit to attending meetings in order to showcase their knowledge. 
The other view suggests that busy directors, who spread their time too thin by taking on too many outside directorships, may not fully understand the business of all the companies where they hold appointments. This is consistent with the argument that CEO-directors face more time constraints due to the burdens of the day-to-day management of their own firms (Booth and Deli, 1996) and directors sitting on several boards may be overstretched in terms of their time and energy (Fich and Shivdasani, 2006). Such lack of detailed knowledge about any of the companies and lack of time reduces their level of confidence and commitment to attend meetings. Indeed, scholars have shown that directors holding more board seats and directors who are CEOs of other companies are significantly more likely to miss board meetings (Lipton and Lorsch, 1992). While previous studies have considered the extent to which an individual director is busy by the number of board appointments they hold, it is also plausible that some directors could be considered busy even without other board commitments. Thus, the question is not about the number of board seats that one holds, but rather one of time availability or constraints. For example, some professions demand more, in terms of time, from the professionals than others. Thus, the less time a typical director has, the more likely he/she will have attendance problems.

H4: The time constraints of outside directors will reduce their attendance rate.

\section{DATA AND METHODOLOGY}

\section{Data}

To test our hypotheses we used survey data from the Korea Corporate Governance Service as well as financial data from the Korea Listed Companies Association (KLCA), arguably the most comprehensive data set for corporations in Korea. Survey data provided information about the characteristics of outside directors, including their attendance at board meetings, 
age, education, profession and study major at university, as well as firm-level information such as payments to outside directors. The remaining firm-level information was obtained from the KLCA database.

\section{Measurement}

Dependent variable: The dependent variable is the percentage of meeting attendance by outside directors.

Independent variables: To test the hypothesis that foreign outside directors are less likely to attend board meetings, we include a binary variable, 1 for non-Korean directors, and 0 otherwise. We use the variable, committee, coded as 1 if a firm appointed outside directors through a committee screening process and 0 otherwise. We chose the committee variable to investigate whether or not average attendance is influenced by how a firm appoints outside directors through an independent selection process. To test the hypothesis that re-appointed directors are more likely to attend board meetings, we use a variable that is grand-mean centred: reappointment. Reappointment is expected to represent an outside director's firmspecific experience/knowledge. To test $\mathrm{H} 4$ that suggests that busy directors are less likely to attend board meetings, we consider different types of jobs as covariates. Our view is that lawyers and medical doctors are usually busier than other professionals, given that their incomes are closely linked to the time they spend working. ${ }^{1}$ We, therefore, use a binary variable, lawyer_doctor, coded as 1 if an outside director's job is either lawyer or medical doctor and 0 otherwise. Similarly we added a binary variable for journalist.

Control variables: We control for firm size. Masulis et al., (2012) find that among firm characteristics, directors are less likely to miss board meetings at larger firms. We also

\footnotetext{
${ }^{1}$ Information about the number of board positions held in other firms is not available.
} 
control for board size. The larger the board, the more free-riding behaviour may occur, since it may be less important that a particular director is not present at the meeting. We control for director's age, expected to capture the level of general experience of outside directors. There is evidence that meeting fees are effective at influencing directors' attendance behaviour (Adams and Ferreira, 2008). We, therefore, control for the fees made to directors for attending meetings.

\section{Econometric Model}

The multilevel random coefficients model for investigating the response variable $\mathbf{Y}$ is:

$$
\mathbf{Y}=\mathbf{X} \boldsymbol{\beta}+\mathbf{Z}^{(L)} \mathbf{u}^{(L)}
$$

where $\mathbf{X}$ and $\boldsymbol{\beta}$ denote the matrix of all covariates in the fixed parts and the corresponding parameters respectively. The second part of equation (1) refers to the random residual errors, $\mathbf{u}$, at (all) different levels $(L)$. The matrix of covariates in the random parts, $\mathbf{Z}$, may or may not include $\mathbf{X}$.

The fixed part of the model, $\mathbf{X} \boldsymbol{\beta}$, is directly required to investigate the empirical hypotheses. The random part of the model (1), $\mathbf{Z}^{(L)} \mathbf{u}^{(L)}$, provides detailed information on the variance of the response variable. If $\mathbf{Z}=\mathbf{I}$ and $L=1$, the random residual $\mathbf{u}$ will collapse to the errors at the lowest level (usually denoted by e), assumed to have a normal distribution with a mean of zero and a common variance of $\boldsymbol{\varepsilon}^{2}$ at all the higher levels. Otherwise, the second part of the equation denotes the residual error terms at the higher level, depending on the dimension of $L$, assumed to be independent from $\mathbf{e}$ and to have a multivariate normal distribution with a mean of zero. 
We use multilevel random coefficients models to examine our empirical hypotheses for three reasons. First, outside directors' participation in board meetings is the result of their behavioural decisions. Conceptually, an individual's decisions are influenced by the organisation he/she belongs to. Hunter and van den Eeden (1993) contend that the effects of social context on individuals, if any, should be mediated by intervening processes that depend on the characteristics of the social context. In contrast to traditional models, the multilevel model allows us to examine cross-level interactions. Second, our dataset has nested multilevel characteristics. The repeatedly observed occasions are nested in the personal level (i.e., outside directors), which is in turn nested in the firm. Third, the greatest advantage of the multilevel random coefficients models is that it can model random residuals at all levels of analysis simultaneously. Thus, economic relationships between variables can be examined at both within- and between-subject levels (in addition to interactions between the cross levels). The conceptualising error term allows us to compare error variance. ${ }^{2}$

\section{RESULTS}

\section{Descriptive Results}

The last column of Table 1 shows that the board meeting attendance rate by outside directors varies widely. It ranged from zero to 100 percent. The second column of the table also indicates that the proportion of always-attending groups (36.93\%) is disproportionately high.

\footnotetext{
${ }^{2}$ The fundamental shortcoming of traditional OLS and weighted LS is that they do not model error properly, which can result in misleading parameter estimations.
} 
In contrast, 5.66 percent of respondents answered they never attended the required board meetings. The median value of the attendance rate is 86 percent. $^{3}$

\section{Table 1 about here}

Table 2 shows that there is no pattern in the waves of average attendance rates between 2002 and 2006. Mean values vary between a low of 68.69 percent in 2003 and a high of 72.14 percent in 2005, with similar standard deviations. The table also indicates that not only the mean values but also other statistics, including low and high percentiles and median values of the attendance rates, are consistently lower in 2003 than in other years.

\section{Table 2 about here}

Table 3 reports the types of jobs held by outside directors, showing that executive managers (of other firms) and professors are the most common. The figures in the second column show that the proportion of outside directors accounted for by these two jobs combined is 55 percent.

\section{Table 3 about here}

Table 4 indicates that the most popular study major of appointed outside directors is business, accounting for 44 percent of the total observations, followed by law (21 percent). The proportion of outside directors' study majors that are directly related to business operations and the firm's strategic decisions is 65 percent.

\section{Table 4 about here}

\footnotetext{
${ }^{3}$ The mean attendance rate in Korea is 71 percent. In contrast to the case of Korea, the SEC in the US stipulates that board members must meet the 75 percent participation threshold level.
} 
In summary, our dataset indicates that attendance rates by outside directors during 2002-2006 have a skewed distribution, and that appointed outside directors have variety of socialeconomic positions. Based on this observation, we devised the following estimation strategy. First, we use natural logarithm of the attendance rate as a response variable to reduce the skewness problem. Second, we use the nonlinear estimation method after recoding the attendance rate into a binary variable.

\section{Estimation Results}

The estimation results in Table 5 are based on three-level random coefficients models, where the repeatedly observed attendance rate by outside directors is nested in the personal (i.e., outside director) level, which in turn is nested in the firm level. Attendance rates by outside directors are the response variable.

Model 1 in Table 5 refers to the intercept-only model without covariates, which is mainly to investigate the variance of the response variable. The random part of the output reports that total variance of attendance provides a baseline for the estimation of explained and unexplained variance. The sum of these intra-class correlations is 81 percent, suggesting that total variance of the attendance rate is largely explained by variations at the firm and individual levels, with almost equal weights. ${ }^{4}$

The estimation results from Model 2 strongly support Hypothesis 1. The sign of the estimated coefficient of the non-Korean variable is negative and significant at the 1 percent

\footnotetext{
${ }^{4}$ The variance at the individual level (i.e., outside director) is 1.238 with a standard error of 0.064 , and variance at the firm level is 1.171 with a standard error of 0.113 . The variance of unexplained residuals is 0.562 . The intra-class correlation at the firm level, calculated by $1.171 /(1.171+1.238+0.562)$, shows that 39.4 percent of the variance of the attendance rate is at the firm level. The calculation of intra-class correlation at the personal level is 41.7 percent.
} 
level. It indicates that the expected attendance rate of a foreign outside director is around 84 percent less than that of a Korean outside director. With $\chi^{2}(3)=252$ for the comparison of the change in deviance from Model 1, Model 2 is considered as having a better fit of between the two models. Compared to Model 1, the inclusion of the individual level variable reduces the individual level variance in the random part by about 20 percent (i.e., from 1.238 to $0.998)^{5}$

The estimation results of Model 3 in Table 5 support our research hypothesis H2 at the 1 percent significance level. The estimated coefficient suggests that the average attendance rate for firms that appoint outside directors through a committee is 35 percent higher than that of other firms. Outside directors appointed by committees are assumed to be more independent than those appointed by personal recommendation, including incumbent CEOs and controlling shareholders. Independent outside directors seem to have greater motivation to participate in a firm's strategic decisions as well as the commitment to monitor both management and controlling shareholders.

\section{Table 5 about here}

An examination of a cross-level interaction variable is useful in examining the intervening process of the effects of social context on individuals (Hunter and Eeden 1993). ${ }^{6}$

\footnotetext{
${ }^{5}$ The inclusion of the individual level increased the group-level variance (i.e., the lowest row of random part) by around 5 percent, which is similar to Hox (2000).

${ }^{6}$ The possibility of the heterogeneous effect of a higher level variable on a lower level variable has been acknowledged in the educational research literature. Cronbach and Webb (1975) conjectured that effective teachers were only effective with certain types of students, and not necessarily effective with all students to the
} 
In our estimation model, both random intercept and slope at level one are assumed to be a function of an outsider's characteristics (i.e., non-Korean), which in turn are a function of the firm's characteristics (i.e., committee). ${ }^{7}$

The estimated coefficient of the cross-level interaction variable is significant at the conventional level. The sign of this coefficient is positive, implying that an independent selection process helps foreign outside director to attend board meetings to a greater extent than Korean outside directors. In other words, an independent selection process for outside directors has an effect on the attendance rates of outside directors.

Graph 1 shows clearly this effect of an independent selection process on attendance. The upper solid line shows the average attendance rate of foreign outside directors (i.e., nonKorean=0) in a firm that appointed these outside directors without an independent appointment process (i.e., committee $=0$ ) in comparison to the average attendance rate of Korean outside directors in a firm that appointed these outside directors through an independent appointment process (i.e., committee $=1$ ). The positive effects of a change in the appointment process for outside directors, from lack of independence (i.e., committee $=0$ ) to an independent process (i.e., committee $=1$ ), on log attendance rate of foreign outside directors is 0.279 (=3.963-3.684). This positive effect of an independent appointment process on log attendance of Korean outside directors (i.e., non-Korean=1) is 1.393 (=2.798-1.405).

\section{Graph 1 about here}

same extent. Raudenbush and Bryk (1986) also proposed different effects of public schools on pupils’ maths scores.

\footnotetext{
${ }^{7}$ We did not impose any restrictions on the structure of covariance between random intercept and slope at the individual level.
} 
The difference between 1.384 and 0.279 represents the egalitarian effect of independent appointment on log attendance rate. In an untabulated table, the correlation between the non-Korean (committee) variable and the interaction variable is 0.59 (0.21), and all these are significant at the 1 percent level. The correlation between non-Korean and committee is 0.16 and is also significant at the 1 percent level. Both of these correlations imply that the interaction variable, non-KoreanXcommittee, is meaningful. ${ }^{8}$ This finding suggests that a better corporate environment for the outside director system, measured by an independent appointment process, encourages outside directors' board meeting attendance in a more egalitarian way.

The results in Model 5 indicate that only firm-specific experience is important in facilitating outside directors' attendance at board meetings. On average, reappointed outside directors attend board meetings more than newly appointed outside directors by around 15 percent. This finding is consistent with research hypothesis 3. In this estimation, we used the reappointment variable at the beginning of each year to mitigate the problem caused by potential reverse causality.

In Model 6, we added four additional variables to Model 5 with a view to investigating empirical hypotheses H4 (time availability). The estimated coefficients of these variables in Model 6 show negative signs as expected and are significant at the conventional level. Alternatively, we used manager for the proxy of time availability and found a positive sign with significance at 10 percent level (not reported).

We also included level of education, on the assumption that highly educated people tend to be busier than less educated ones. However, the estimated coefficient of education is

\footnotetext{
${ }^{8}$ The estimated regression coefficient of the non-Korean variable on the committee variable is also significant at the 1 percent level.
} 
not significant. Another possible interpretation of this result is that more educated people believe their market value in the outside director market is higher than that of less educated ones, particularly in an economy (i.e., Korea) where education is highly valued. Therefore, more educated people have less motivation to ‘sell’ themselves (Nelson 1974).

The estimated coefficients of accountdegree, businessdegree and lawdegree show positive signs and are significant at the 1 percent level. All of these three covariates are binary variables that indicate outside directors' study majors at university. All of these degrees are directly associated with business operations and a firm’s strategic decisions. In an untabulated table, we added a binary variable for outside directors who studied social science and a binary variable for those who studied pharmacy. Neither of these two variables was significant, supporting the proposition that professional knowledge about corporate strategic decisions is important in encouraging outside directors to attend board meetings.

\section{DISCUSSION ABOUT THE MAIN FINDINGS}

We consider Model 6 in Table 5 to be the preferred full model. All estimated coefficients associated with our research hypotheses in this model show the expected signs and are significant at least at the conventional level. The statistics of $\chi^{2}(6)$ for the change in deviance from Model 5 to Model 6 are also significant at the conventional level.

To examine the relative magnitudes of each covariate on the response variable, we standardised the estimated coefficients of Model 6 by multiplying the standard deviation of each covariate with the corresponding estimated coefficients. ${ }^{9}$ The figures in the last column in Table 5 are in percentage form. The results suggest that foreign outside director, the

\footnotetext{
${ }^{9}$ In fact, we need to divide these numbers by the standard deviation of the response variable to recover the standardised coefficients. Dropping this common denominator does not affect the relative magnitudes.
} 
independent selection of the outside directors and their interaction are overall the most important factors in influencing attendance rates. The cross-level interaction between nonKorean and committee is significant, and this suggests that the mediating effects of both personal and firm characteristics should be taken into consideration in analysing outside directors’ board meeting attendance.

Second, outside directors' personal knowledge (regardless of generic professional knowledge about business operations or firm-specific knowledge) seemed to be the second most important factor. Financial literacy and legal knowledge are crucial requirements to enable outside directors to monitor managerial misbehaviour as well as to provide advice to management. Our estimation results also indicate that firm-specific knowledge from past experience is important.

Interestingly, the results in Table 5 show that outside directors who are lawyers reduce the attendance rate whereas outside directors who studied law at university increase the attendance rate. Studying law at university does not necessarily guarantee a job as a lawyer in Korea. Law students need to pass an extremely competitive national examination to qualify as a lawyer. Lawyers usually work for a law firm, where a performance-based reward system (i.e., partnership structure) is common. Therefore, the opportunity cost of attending board meetings as an outside director is expected to be significantly higher for lawyers than for others. By contrast, people who studied law but did not pass the national qualification examinations tend to work in private or public organisations. The positive and significant coefficient of lawdegree indicates that professional legal knowledge is important in determining board meeting attendance.

Third, financial incentive and time availability are almost equally important but have the opposite effects. This relatively low importance of financial incentive, compared to foreign outside director and personal professional knowledge, is due partly to the poorly 
designed financial incentive system for outside directors. Firms pay an equal amount to all outside directors irrespective of their attendance at board meetings, level of educations, experience or profession. ${ }^{10}$ In addition, the absolute amount of payment is small. The average annual payment to outside directors is around 23,000 US dollars, which is similar to the wage of a university graduate without work experience.

Fourth, the results also imply that the overall experience of outside directors, measured by age, and level of education are not significant.

\section{Further Tests - The Effect of the Corporate Environment Associated with Outside}

\section{Directors}

To investigate further the effects of the corporate environment on outside directors' attendance rates, we selected three additional variables: exceedingrate, boardownership, and free cash flows $(F C F)$. Exceedingrate, measured by a proportion of (outsiders/board members) that exceeds the level that is legally required, represents a firm's voluntary appointment of outside directors. The amended Securities and Exchange Law stipulates that a large firm (i.e., with assets of no less than 2 trillion won) should appoint outside directors to at least 50 percent of the positions on its board. The Listing Act also requires all listed firms to have a ratio of at least 25 percent of outside directors to board members.

We expect exceedingrate to capture a firm's 'active’ appointment of outside directors and thus its support for the newly introduced outside director system. Estimation outcomes in Table 6 (Model_c1) show that the exceedingrate is positive and significant at the 7 percent level, suggesting that a corporate environment that supports the outside director system

\footnotetext{
${ }^{10}$ This unilateral and predetermined payment, however, mitigates the endogeneity problem caused by reverse causality.
} 
encourages outside director to attend more board meetings. Model_c2 added an inter-class interaction variable, calculated by interaction between non-Korean and exceedingrate, to Model_c1. This interaction is significant at the 1 percent level with a positive sign, which is the same as the effect of the independent appointment process in Table $5 .^{11}$

In an untabulated table, we added a common time-trend and an interaction between this and exceedingrate separately to Model_c2 (Column 2). None of these additional variables were significant. The statistics of chi-square for the change in deviance from Model_c2 and model with year (the interaction variable) additionally was $0.134(0.00)$. This finding suggests that there is no significant role of time-trend in influencing board meeting attendance by outside directors.

Models_c3-c4 and Models_c5-c6 respectively include boardownership and FCF as covariates to represent corporate governance. Boardownership denotes equity ownership by internal board members and thus is expected to have a negative sign. Jensen (1986) and Easterbrook (1984) suggested that free cash flow is an indication of poor governance. This interpretation assumes that management fails to appropriately use cash flows for profitable projects, given the possible choice of projects. The estimation results of Model _c3 Model_c6 support the finding in Model_c1 and Model_c2. ${ }^{12}$

\section{Table 6 about here}

\section{ROBUSTNESS CHECK}

\footnotetext{
${ }^{11}$ All the correlations between exceedingrate, non-Korean and the interaction variable are significant at the 1 percent level. The statistics of chi-square for the change in deviance suggest that Model_c2 is preferred although the direct effect of exceedingrate is no longer significant.

${ }^{12}$ Although correlations between the interaction variables are not significant, all inter-class interaction variables are significant at the conventional level.
} 
To examine the reliability of the estimated coefficients and standard errors, we ran the threelevel random coefficients model (Model 6 in Table 5) on a yearly basis (not reported).

We made two major findings. First, all these estimates are in line with the estimations found by the preferred full model. All the yearly-basis estimated coefficients have the same signs. Overall statistical significances, measured by the distance between the two connected lines in the graph, are similar for the two estimates, although some of the significances of age, lawyer_doctor, businessdegree and lawdegree variables dropped sharply in 2003 and to some extent in 2004. Second, there is no consistent pattern to whether yearly-basis estimates are overestimates in comparison to the pooled ones. The graph shows that almost 40 percent of the yearly-basis estimates are overestimates, but lawdegree is an underestimate. The estimated coefficients of journalist and businessdegree are relatively similar between yearlybasis and the pooled estimations.

Because of some irregularity in the estimated coefficients in year 2003 or 2004, we reran the preferred full model (Model 6 in Table 5) excluding year 2003 or 2004 (Columns 1 and 3 in Table 7). Columns 2 and 4 in Table 7 are modifications of these calculations by substituting exceedingrate and its interaction with non-Korean for committee and its interaction with non-Korean. Therefore, all model specifications consider a positive corporate attitude to the outside director system and inter-class interaction between foreign outside directors and this positive corporate environment.

All estimation results are consistent with the preferred full model with the full sample as indicated by Model 6 in Table 5. Foreign outside director (non-Korean) and independent appointment process (committee) and their inter-class interaction remain significant at the 1 percent level. The inter-class interaction is also significant at the conventional level when we use exceedingrate in place of committee, confirming the importance of a firm's environment 
being favourable to the outside director system. Professional knowledge (businessdegree, lawdegree and accountingdegree) and firm-specific knowledge (reappointment) are also significant at the conventional level. However, the statistical significance of the variables for time availability (education, lawyer_doctor, journalnist) declined somewhat. The payment variable seemed to be affected the most by the exclusion of the year 2003 or 2004 .

\section{Table 7 about here}

Using our preferred full model (Model 6 in Table 5), we obtained empirical Bayses predictions of occasions, outside directors (i.e., personal level) and firm random effects (not reported). These graphs imply that there are no serious violations of the normality assumption, particularly for the occasion and the personal level. However, we observe that there are some possibilities of violations of the normality assumption at the firm level. Although the majority of observations are symmetric along zero, a large portion are also scattered at the bottom of the graph. We will examine this potential problem below.

\section{THE ISSUES OF ENDOGENEITY}

A concern is the possible endogenity associated with the correlation between the included covariates and unobserved firm-specific effects. Firm-specific effects such as a unique managerial style may lead to a preference to appoint postgraduates or aged outside directors. To control for this firm-specific effect, we included a series of firm-identifiers in the estimation model. We therefore checked the robustness of our full model (Model 6 in Table 5) by estimating both the model without considering hierarchical structure together with firmidentifiers (Columns 1-4 in Table 8) and the two-level random coefficients model (Columns 5-6). 
Our estimation results are consistent with the full preferred model, although there are some caveats to be mentioned. The sign of the age variable sometimes became negative but was not significant. Education became significant at the one percent level. Exceedingrate, as a proxy for a favourable corporate environment towards the outside director system, seemed to fit better with lower-level models than with the three-level hierarchy models.

The estimation results also illustrate the Robinson effect of aggregation data: the standard errors of the estimates from non-hierarchical models are generally of lower value than those from the multi-level models.

\section{Table 8 about here}

\section{DISCUSSION AND CONCLUSIONS}

This paper examined the antecedents of outside directors' meeting attendance. In the context of Korean governance studies our study goes beyond extant studies that focus on the appointments of outside directors. Using three-level random coefficients models and using a unique dataset for Korea, where the corporate governance system has undergone substantial reform, the study shows that both outside directors' personal characteristics and the social context are crucial in understanding board meeting attendance.

Specifically, this study finds that foreign outside directors are less inclined to attend board meetings. As discussed earlier this behaviour could be attributed to a number of things including the geographical distance that exists between the firm headquarters and foreign countries and language barriers. 
The study also finds that outside directors who are appointed through the screening process are more likely to attend board meetings, suggesting the importance of a professional nomination and selection system of directors.

Moreover, the study finds that re-appointed directors are more likely to attend board meetings. This suggests that firm-specific knowledge gained through past experience in an outside director's own firm is important. An outside director who is reappointed is expected to have better knowledge of the firm because of learning by experience. This also suggests that re-appointed directors may want to repay the trust placed on them to continue serving the company by at least attending meetings. Indeed, as argued earlier, directors' re-appointment to the board signifies the trust and level of satisfaction that shareholders have in the individuals. In addition, the study finds that busy directors are less likely to attend board meetings, an indication of their time commitment elsewhere. While a better measure of directors' busyness would have been the number of board seats held by an individual director, our approach of using professions deemed to be busy still give a good indicator of the subject at hand.

The paper makes a number of contributions to corporate governance literature. To start with the issue of board attendance on its own is an important one. For instance, when a third or more of board seats are vacant or a few members are habitually absent, the board cannot be fully informed, cannot raise tough questions and cannot reach independent conclusions as a group. This paper, therefore, provides an awareness of the fact that characteristics of outside directors are salient in their behaviour and level of commitment in the context of board meetings attendance. Moreover, the study adds to the theory of corporate governance by examining the attendance of board meetings through the lens of organizational 
commitment. Such an approach lends to subsequent analysis of board performance as a function of directors' attendance at meetings.

This study has implications for practice, providing guidance on which type of outside director is likely to attend board meetings. As such this study, although carried out in South Korea, could also be useful to firms in countries in the region that are close culturally.

\section{Limitations and areas for further research}

Notwithstanding the relevance and timeliness of this study, we identify some limitations and suggest avenues for further research. First, while this study provides insight into the characteristics of board directors that allow or reduce the likelihood of attending board meetings, the unique circumstances of the context i.e. Korea, may allow limited generalizability of our findings. Perhaps, an extension of this study with firms from several countries could provide a better understanding of this subject.

Second, we used selected professions to proxy for the busyness of the director. While we are confident that the results provide a good indication for the behaviour of a busy director, however, future studies could employ the number of board seats held by an individual director as a proxy for a busy director.

Using the organizational commitment lens, future studies could examine the effect of board meeting attendance by various types of directors examined in this study (foreign, independently screened directors, re-appointed directors and busy directors) on firm performance.

\section{References}

Adams, R.B. \& Ferreira, D. (2008). Regulatory pressure and bank directors' incentives to attend board meetings, Working Paper No 203/2008. ECGI. 
Black, B. S. Jang, H., \& Kim, W. (2006), Does corporate governance predict firms' market values? Evidence from Korea. Journal of Law, Economics and Organisation, 22: 366-413.

Boden, D. (1995). Agendas and arrangements: everyday negotiations in meetings in The discourse of negotiation: Studies of language in the workplace. A. Firth (ed), 83-100. Oxford: Pergamon Press.

Cai, J., Garner, J.L. \& Walkling, R.A. (2009). Electing directors, Journal of Finance 64, 2389-2421.

Carcello, Hermanson \& Neal, (2002). Board characteristics and audit fees, Contemporary Accounting Research, 19(3): 365-384.

Carter, D.A., Simkins, B.J. \& Simpson, W.G. (2003). Corporate governance, board diversity, and firm value, Financial Review, 38(1): 33-53.

Chang, Y.K., Oh, W-Y, Park J.H., \& Jang, M.G., (2015), Exploring the relationship between board characteristics and CSR: Empirical evidence from Korea, Journal of Business Ethics, forthcoming.

Chizema, A. \& Kim, J. (2010). Outside directors on Korean boards: Governance and institutions, Journal of Management Studies,_(47)_1: 109-129.

Chizema, A. \& Shinozawa, Y. (2012). The 'company with committees': Change or continuity in Japanese corporate governance, Journal of Management Studies, 49: 77-103.

Cho, D.\& Kim, J. 2007.Outside directors, ownership structure and firm profitability in Korea, Corporate Governance: An International Review, 15, 239-250.

Choi, J.J., Park, S.W. \& Yoo, S.S. (2007). The value of outside directors: Evidence from corporate governance reform in Korea, Journal of Financial and Quantitative Analysis, 42(4): 941-962.

Conger, J., Finegold, D. \& Lawler III, E. (1998). Appraising boardroom performance, Harvard Business Review, (76): 136-148.

Cronbach, L. J. \& Webb, N. 1975. Between class and within class effects in a reported aptitude $\mathrm{x}$ treatment interaction: A reanalysis of a study by G.L. Anderson, Journal of Educational Psychology, 67: 717-24.

Easterbrook, F.H. (1984). Two agency-cost explanations of dividends, American Economic Review, 74: 650-659.

Ebrey, P.B., Walthall, A. \& Palais, B., (2009) Pre-Modern East Asia: A cultural, social and political history, Houghton Mifflin Company, Boston, MA, USA.

Fama, E.F., \& Jensen, M.C. (1983), Separation of ownership and control, Journal of Law and Economics, 26(2), 301-325. 
Fich, E.M. \& Shivdasani, A. (2006). Are busy boards effective monitors? Journal of Finance, 61(2): 689-724.

Gilsdorf, J.W. (1986). Executives' and academics' perceptions on the need for instruction on written persuasion, Journal of Business Communication 23:55-68.

Guth W.D., \& MacMillan, I.C. (1986). Strategy implementation versus middle management self-interest, Strategic Management Journal 7(4): 313-327.

Hermalin, B.E., \& Weisbach, M.S. (1991). The effects board composition and direct incentives on firm performance, Financial Management, 20(4):101-12.

Hillman, A.J., Cannella Jr. A. \& Paetzold, R.L. (2000). The resource dependence role of corporate directors: Strategic adaptation of board composition in response to environmental change, Journal of Management Studies 37(2):235-55.

Hofstede, G. (1997). Cultures and organisations, New York: McGraw Hill.

Hox, J.J. (2000). Multilevel analysis of grouped and longitudinal data, in Littel, T.D., Schnabel, K.U.and Baumert, J., (eds.) Modeling longitudinal and multiple-group data, Practical issues, applied approaches, and specific examples, Hillsdale, NJ: Lawrence Erlbaum Association.

Hunter, H.J.M \& van den Eeden, P. (1993). The multilevel design. A guide with an annotated bigliography, 1980-1993, London: Greenwood Press.

Hyek, F.A. (1945). The use of knowledge in society, American Economic Review, 35: 519530.

Jarzabkowski, P. \& Seidl, D. (2008). The role of meetings in the social practice of strategy. Organization Studies, 29: 1391-426.

Jensen, M.C. (1986). The agency costs of free cash flow: Corporate finance and takeovers, American Economic Review, 76(2):323-329.

Kim, J.H \& Lee, WR, (2015). Issues and improvement measure of outside director system: From a board composition and behaviours of outside director perspective, KDI Focus, Korea Development Institute, Seoul Korea.

Knyazeva, A., Knyazeva, D. \& Masulis, R. (2011). Local director talent and board composition. Working paper, University of Rochester.

Kreft, I.G.G., de Leeuw, J., \& Aiken, L. (1995). The effects of different forms of centering on hierarchical linear models, Multivariate Behavioural Research, 30:1-22.

Kwon, W., Clarke, I. \& Wodak, R. (2014). Micro-level discursive strategies for constructing shared views around strategic issues in team meetings, Journal of Management Studies, 51:265-290.

Lerner, J. (1995). Venture capitalists and the oversight of private firms, Journal of Finance, 50: 320-318. 
Linck, J.S., Netter, J.M., \& Yang, T.(2008). The determinants of board structure, Journal of Financial Economics, 87: 308-328.

Lipton, M. \& Lorsch, J. (1992). A modest proposal for improved corporate governance, Business Lawyer, 48: 59-77.

Liu, H., Wang, H. \& Wu, L. (2014). Removing vacant chairs: Does independent directors' attendance at board meetings matter? Journal of Business Ethics, 1-19.

Lu, G. \& Sun, J. (2010). Director tenure and independent audit committee effectiveness, International Research Journal of Finance and Economics, 51: 176-189.

Masulis, R. W., Wang, C. \& Xie, F. (2012). Globalizing the boardroom - the effects of foreign directors on corporate governance and firm performance, Journal of Accounting and Economics, 53(3): 527-554.

Milgrom, P., \& Roberts, J. (1992). Economics, Organisation and Management, Prentice Hall: Upper Saddle River, New Jersey.

Min, B. (2013). Evaluation of board reform: An examination of the appointment of outside directors, Journal of the Japanese and International Economies, 29:21-43.

Min, B. \& Verhoeven, P., (2013), Outsider board activity, ownership structure and firm value: Evidence from Korea, International Review of Finance, 13:187-214.

Min, B. \& Smyth, R., (2014), Corporate governance, globalisation and firm productivity, Journal of World Business, 49:372-385.

Mintzberg, H. (1973). The Nature of Managerial Work. New York: Harper \& Row.

Mowday, R.T., Porter, L.W., \& Steers, R.M. (1982). Employee- organizational Linkages: The Psychology of Commitment, Absenteeism, and Turnover. Academic Press: New York.

Nelson, P. (1974). “Advertising as information,” Journal of Political Economy, 84: 729-54.

Ntim, C.G. \& Osei, K.A. (2011). The impact of corporate board meetings on corporate performance in South Africa, African Review of Economics and Finance, 2(2): 83100.

Organisation for Economic Co-operation and Development (OECD). (2001). Corporate Governance in Asia: A comparative perspective, Paris: OECD.

O’Reilly, C. A. \& D. F. Caldwell, (1981). The Commitment and job tenure of new employees: Some evidence of Post-decisonal justification, Administrative Science Quarterly,26: 597-616.

Peffer, J. \& Salancik, G.R. (1978). The external control of organization: A resource dependence perspective, Harper \& Row: New York.

Perrow C. (1986). Complex Organizations: A Critical Essay (3rd ed). Random House: New York. 
Raudenbush, S.W. \& Bryk, A.S. (1986). A hierarchical model for studying school effects, Sociology of Education, 59: 351-7.

Reed, D., (2002). Corporate governance reforms in developing countries. Journal of Business Ethics, 37:223-247.

Salancik, G.R. (1977). Commitment and the control of organizational behaviour and belief. In B.Staw and G. Salancik (eds), New directions in organizational behaviour, Chicago: St Clair.

Schwartzman, H. B. (1989). The meeting: gatherings in organizations and communities. NewYork: Plenum

Selznick P. (1957). Leadership in Administration. University of California Press: Berkeley, CA.

Shleifer, A., \& Vishny, R.W. (1993). Corruptions, Quarterly Journal of Economics 108(3): 599-617.

Spence, A.M. (1973). Market signalling: Information transfer in hiring and related process, Cambridge, MA: Harvard University Press.

Vafeas, N. (1999). Board meeting frequency and firm performance, Journal of Financial Economics, 53: 113-142.

Vafeas, N. (2003). Length of board tenure and outside director independence, Journal of Business Finance and Accounting, 30: 1043-1064.

Xie, B., Davidson, W.N \& DaDalt, P.J. (2003). Earnings management and corporate governance: the role of the board and the audit committee, Journal of Corporate Finance, 9(3): 295-316.

Yermack, D. (2004). Remuneration, retention, and reputation incentives for outside directors, Journal of Finance, 59(5): 2281-2308. 
TABLE 1.

FREQUENCY OF BOARD MEETING ATTENDANCE RATES BY OUTSIDE DIRECTORS

\begin{tabular}{lcccc}
\hline & \multicolumn{2}{c}{ Point statistics } & \multicolumn{2}{c}{ Cumulative statistics } \\
\cline { 2 - 5 } $\begin{array}{l}\text { Attendance rate } \\
(\%)\end{array}$ & Frequency & $\%$ & Frequency & $\%$ \\
\hline 0 & & & & \\
25 & 294 & 5.66 & 294 & 5.66 \\
50 & 38 & 0.73 & 857 & 16.49 \\
75 & 113 & 2.17 & 1,408 & 27.09 \\
$(86)$ & 100 & 1.92 & 2,093 & 40.27 \\
100 & & & & $(50.00)$ \\
\hline
\end{tabular}

This table reports point frequency (second and third columns) and cumulative frequency (last two columns) of outside directors' board meeting attendance by different strata of attendance rates (first column). The cumulative statistics for attendance rate $0-25$ include an attendance rate of 25 percent. The remainder of the cumulative statistics for attendance rates also include the upper figure but exclude the lower figure. Numbers in brackets denote median value.

TABLE 2.

ANNUAL ATTENDANCE RATE BY OUTSIDE DIRECTORS OVER 2002-2006

\begin{tabular}{lllllllll}
\hline year & $\mathrm{N}$ & mean & sd & P25 & P50 & P75 & min & max \\
\hline 2002 & 1,191 & 72.08 & 33.45 & 50 & 87.50 & 100 & 0 & 100 \\
2003 & 1,056 & 68.69 & 34.67 & 40 & 83 & 100 & 0 & 100 \\
2004 & 1,118 & 70.67 & 33.61 & 45.05 & 85.71 & 100 & 0 & 100 \\
2005 & 1,218 & 72.14 & 33.32 & 50 & 87 & 100 & 0 & 100 \\
2006 & 614 & 71.34 & 33.77 & 48 & 86 & 100 & 0 & 100 \\
\hline Total & 5,197 & 71.01 & 33.76 & 50 & 86 & 100 & 0 & 100 \\
\hline
\end{tabular}

sd and P respectively denotes standard deviation and percentiles. 
TABLE 3.

DISTRIBUTION OF OUTSIDE DIRECTORS' JOB

\begin{tabular}{lll}
\hline Type of Job & Frequency & Percent \\
\hline Accountant & 213 & 4.10 \\
Lawyer & 592 & 2.89 \\
Executive manager & 1,711 & 32.93 \\
Professor & 1,125 & 21.63 \\
Ex-government officer & 271 & 5.22 \\
Medical doctor & 15 & 0.29 \\
\hline Others & 1,275 & 32.94 \\
\hline
\end{tabular}

Others include (external) auditor, medical doctor, banker, journalist, researcher, tax officer.

TABLE 4.

DISTRIBUTION OF OUTSIDE DIRECTORS' UNIVERSITY DEGREE

\begin{tabular}{lll}
\hline Study major & Frequency & Percent \\
\hline Business & 2,279 & 43.82 \\
Engineering & 853 & 16.42 \\
Law & 1,097 & 21.12 \\
Pharmacy & 113 & 2.18 \\
Social Science & 220 & 4.24 \\
Others & 634 & 12.21 \\
\hline
\end{tabular}

Business includes economics, business administration (management), accounting and finance. 
TABLE 5.

ESTIMATION RESULTS FOR ATTENDANCE RATES BY THREE-LEVEL RANDOM COEFFICIENTS MODELS

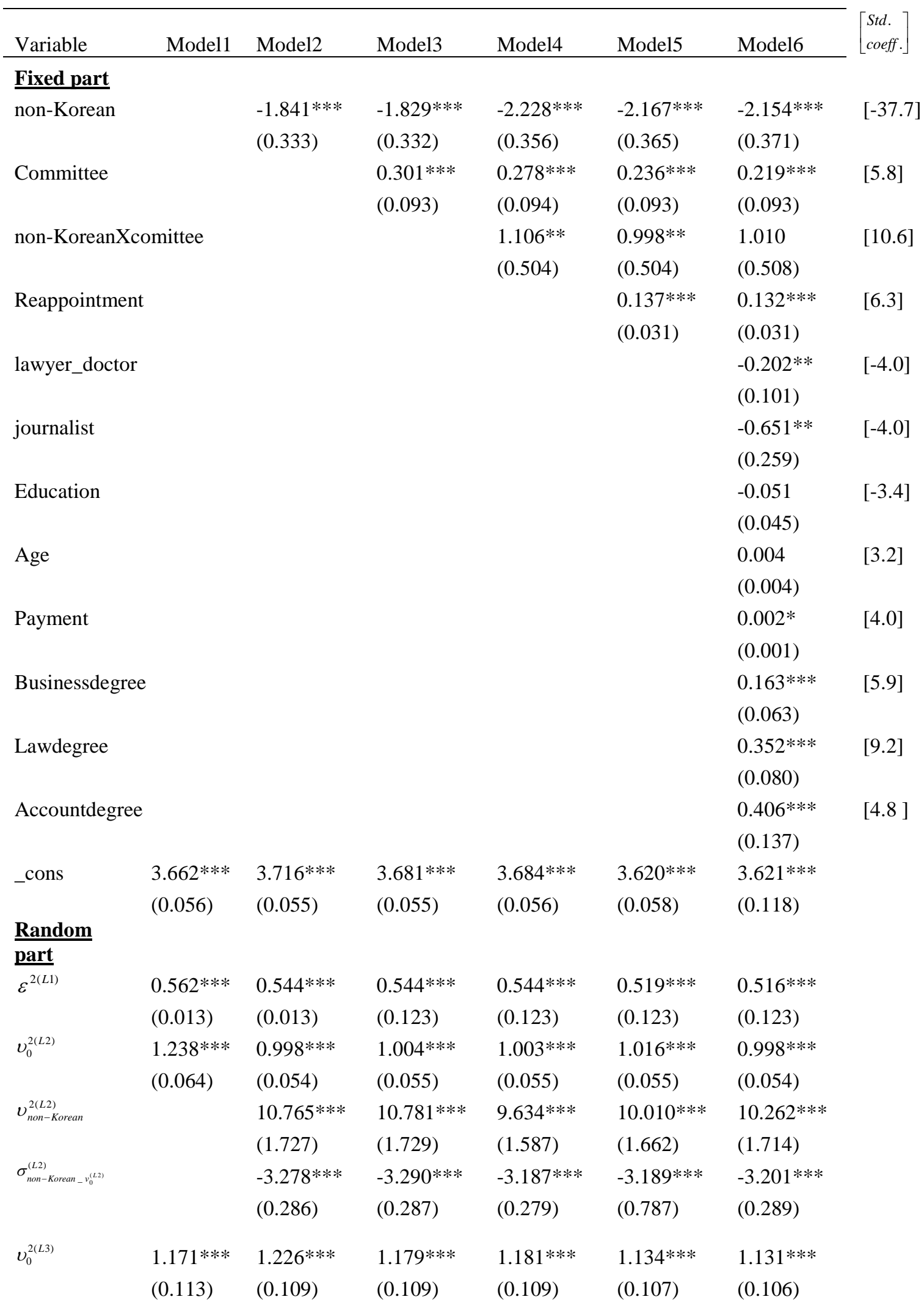




\begin{tabular}{lllllll}
$\mathrm{N}$ & 5197 & 5197 & 5197 & 5197 & 5197 & 5197 \\
Deviance & 15668 & 15416 & 15406 & 15401 & 15173 & 15136 \\
aic & 15677 & 15429 & 15421 & 15419 & 15196 & 15183 \\
\hline
\end{tabular}

Figures in brackets are standard errors. *, **, *** refers to significance at 10,5 and 1 percent level respectively.

TABLE 6.

THREE-LEVEL ESTIMATION RESULTS FOR INTER-CLASS INTERACTIONS WITH CORPORATE GOVERNANCE VARIABLES

\begin{tabular}{|c|c|c|c|c|c|c|}
\hline \multirow[b]{2}{*}{ Variable } & \multicolumn{2}{|c|}{$\begin{array}{c}\text { Exceeding rate of } \\
\text { outside directors }\end{array}$} & \multicolumn{2}{|c|}{$\begin{array}{c}\text { Board's equity } \\
\text { ownership }\end{array}$} & \multicolumn{2}{|c|}{ Free cash flow } \\
\hline & Model_c1 & Model_c2 & Model_c3 & Model_c4 & Model_c5 & Model_c6 \\
\hline non-Korean & $\begin{array}{l}-2.759 * * * \\
(0.470)\end{array}$ & $\begin{array}{l}-3.267 * * * \\
(0.502)\end{array}$ & $\begin{array}{l}-1.808^{* * *} \\
(0.348)\end{array}$ & $\begin{array}{l}-1.668 * * * \\
(0.340)\end{array}$ & $\begin{array}{l}-1.791^{* * *} \\
(0.346)\end{array}$ & $\begin{array}{l}-1.561 * * * \\
(0.361)\end{array}$ \\
\hline exceedingrate & $\begin{array}{l}0.358 * \\
(0.193)\end{array}$ & $\begin{array}{l}0.278 * \\
(0.194)\end{array}$ & & & & \\
\hline exceedingXnon-Korean & & $\begin{array}{l}3.872 * * * \\
(1.343)\end{array}$ & & & & \\
\hline boardownership & & & $\begin{array}{l}-0.210 * * \\
(0.100)\end{array}$ & $\begin{array}{l}-0.046 \\
(0.105)\end{array}$ & & \\
\hline boardownXnon-Korean & & & & $\begin{array}{l}-1.706^{* * *} \\
(0.336)\end{array}$ & & \\
\hline FCF & & & & & $\begin{array}{l}-0.214 \\
(0.295)\end{array}$ & $\begin{array}{l}-0.110 \\
(0.298)\end{array}$ \\
\hline FCFXnon-Korean & & & & & & $\begin{array}{l}-4.553^{* * *} \\
(1.918)\end{array}$ \\
\hline reappointment & $\begin{array}{l}0.185^{* * *} \\
(0.039)\end{array}$ & $\begin{array}{l}0.187 * * * \\
(0.039)\end{array}$ & $\begin{array}{l}0.147 * * * \\
(0.032)\end{array}$ & $\begin{array}{l}0.148^{* * *} \\
(0.032)\end{array}$ & $\begin{array}{l}0.152 * * * \\
(0.031)\end{array}$ & $\begin{array}{l}0.152 * * * \\
(0.031)\end{array}$ \\
\hline lawyer_doctor & $\begin{array}{l}-0.178 \\
(0.138)\end{array}$ & $\begin{array}{l}-0.180 \\
(0.137)\end{array}$ & $\begin{array}{l}-0.202^{* *} \\
(0.101)\end{array}$ & $\begin{array}{l}-0.205^{* *} \\
(0.102)\end{array}$ & $\begin{array}{l}-0.210 * * \\
(0.102)\end{array}$ & $\begin{array}{l}-0.211^{* *} \\
(0.102)\end{array}$ \\
\hline journalist & $\begin{array}{l}-0.745^{* *} \\
(0.342)\end{array}$ & $\begin{array}{l}-0.740 * * \\
(0.342)\end{array}$ & $\begin{array}{l}-0.744^{* * *} \\
(0.272)\end{array}$ & $\begin{array}{l}-0.742 * * * \\
(0.272)\end{array}$ & $\begin{array}{l}-0.703^{* * *} \\
(0.264)\end{array}$ & $\begin{array}{l}-0.703^{* * *} \\
(0.264)\end{array}$ \\
\hline education & $\begin{array}{l}-0.052 \\
(0.057)\end{array}$ & $\begin{array}{l}-0.051 \\
(0.057)\end{array}$ & $\begin{array}{l}-0.046 \\
(0.046)\end{array}$ & $\begin{array}{l}-0.045 \\
(0.046)\end{array}$ & $\begin{array}{l}-0.064 \\
(0.046)\end{array}$ & $\begin{array}{l}-0.064 \\
(0.046)\end{array}$ \\
\hline age & $\begin{array}{l}0.005 \\
(0.004)\end{array}$ & $\begin{array}{l}0.005 \\
(0.004)\end{array}$ & $\begin{array}{l}0.004 \\
(0.004)\end{array}$ & $\begin{array}{l}0.004 \\
(0.004)\end{array}$ & $\begin{array}{l}0.004 \\
(0.004)\end{array}$ & $\begin{array}{l}0.004 \\
(0.004)\end{array}$ \\
\hline payment & $\begin{array}{l}0.002 \\
(0.001)\end{array}$ & $\begin{array}{l}0.002 \\
(0.001)\end{array}$ & $\begin{array}{l}0.001 \\
(0.001)\end{array}$ & $\begin{array}{l}0.001 \\
(0.001)\end{array}$ & $\begin{array}{l}0.002 \\
(0.001)\end{array}$ & $\begin{array}{l}0.002 \\
(0.001)\end{array}$ \\
\hline businessdegree & $\begin{array}{l}0.347 * * * \\
(0.084)\end{array}$ & $\begin{array}{l}0.346 * * * \\
(0.084)\end{array}$ & $\begin{array}{l}0.213^{* * *} \\
(0.064)\end{array}$ & $\begin{array}{l}0.213^{* * *} \\
(0.064)\end{array}$ & $\begin{array}{l}0.172^{* * *} \\
(0.064)\end{array}$ & $\begin{array}{l}0.173^{* * *} \\
(0.064)\end{array}$ \\
\hline lawdegree & $\begin{array}{l}0.404^{* * *} \\
(0.106)\end{array}$ & $\begin{array}{l}0.403^{* * *} \\
(0.106)\end{array}$ & $\begin{array}{l}0.377 * * * \\
(0.081)\end{array}$ & $\begin{array}{l}0.378 * * * \\
(0.080)\end{array}$ & $\begin{array}{l}0.360 * * * \\
(0.081)\end{array}$ & $\begin{array}{l}0.361 * * * \\
(0.080)\end{array}$ \\
\hline accountingdegree & $0.390 * * *$ & $0.389 * * *$ & $0.400 * * *$ & $0.399 * * *$ & $0.410 * * *$ & $0.410 * * *$ \\
\hline
\end{tabular}




\begin{tabular}{lllllll} 
& $(0.175)$ & $(0.175)$ & $(0.142)$ & $(0.142)$ & $(0.138)$ & $(0.138)$ \\
_cons & $3.419^{* * *}$ & $3.423^{* * *}$ & $3.618^{* * *}$ & $3.593^{* * *}$ & $3.664^{* * *}$ & $3.658^{* * *}$ \\
& $(0.146)$ & $(0.146)$ & $(0.122)$ & $(0.122)$ & $(0.123)$ & $(0.122)$ \\
$\mathrm{N}$ & & & & & & \\
Deviance & 3852 & 3852 & 4923 & 4923 & 5032 & 5032 \\
aic & 11894 & 11886 & 14304 & 14278 & 14619 & 14612 \\
\hline
\end{tabular}

This table reports estimates from three-level random coefficients models by the MLE method:

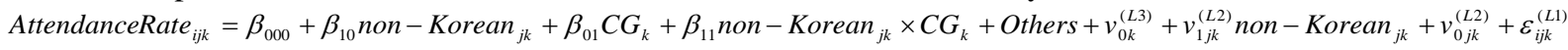

Figures in brackets are standard errors. *, **, *** refers to significance at 10, 5 and 1 percent level respectively. Random parts are not reported for brevity purpose.

TABLE 7.

RESULTS OF ESTIMATION EXCLUDING 2003 OR 2004 FOR THE PREFERRED FULL MODEL AND FIRMS THAT APPOINTED MORE OUTSIDE DIRECTORS THAN THE LEGAL REQUIREMENT

\begin{tabular}{|c|c|c|c|c|}
\hline & \multicolumn{2}{|c|}{ Excluding 2003} & \multicolumn{2}{|c|}{ Excluding 2004} \\
\hline & $\begin{array}{l}\text { Preferred full } \\
\text { model }\end{array}$ & $\begin{array}{l}\text { Firm with } \\
\text { exceeding rate } \\
\text { for outsiders }\end{array}$ & $\begin{array}{l}\text { Preferred full } \\
\text { model }\end{array}$ & $\begin{array}{l}\text { Firm with } \\
\text { exceeding rate } \\
\text { for outsiders }\end{array}$ \\
\hline \multirow[t]{2}{*}{ non-Korean } & $-2.193^{* * *}$ & $-3.343^{* * *}$ & $-2.330 * * *$ & $-3.155^{* * *}$ \\
\hline & $(0.380)$ & $(0.501)$ & $(0.413)$ & $(0.545)$ \\
\hline \multirow[t]{2}{*}{ committee } & $0.332 * * *$ & & $0.228 * * *$ & \\
\hline & $(0.122)$ & & $(0.091)$ & \\
\hline \multirow[t]{2}{*}{ non-KoreanXcommittee } & $1.207^{* *}$ & & $1.119 * *$ & \\
\hline & $(0.532)$ & & $(0.554)$ & \\
\hline \multirow[t]{2}{*}{ exceedingrate } & & $0.204^{*}$ & & $0.150^{*}$ \\
\hline & & $(0.177)$ & & $(0.103)$ \\
\hline \multirow[t]{2}{*}{ non-KoreanXexceedingrate } & & $4.878 * * *$ & & $2.384 *$ \\
\hline & & $(1.158)$ & & $(1.257)$ \\
\hline \multirow[t]{2}{*}{ reappointment } & $0.070^{* *}$ & $0.095^{* *}$ & $0.174 * * *$ & $0.257 * * *$ \\
\hline & $(0.031)$ & $(0.039)$ & $(0.038)$ & $(0.046)$ \\
\hline \multirow[t]{2}{*}{ lawyer_doctor } & $-0.284 * *$ & $-0.207 * *$ & $-0.261 * *$ & $-0.245^{* *}$ \\
\hline & $(0.108)$ & $(0.141)$ & $(0.103)$ & $(0.138)$ \\
\hline \multirow[t]{2}{*}{ journalist } & $-0.485^{* *}$ & -0.463 & $-0.578 * *$ & $-0.582 *$ \\
\hline & $(0.271)$ & $(0.336)$ & $(0.265)$ & $(0.340)$ \\
\hline \multirow[t]{2}{*}{ education } & -0.006 & -0.015 & -0.050 & -0.057 \\
\hline & $(0.048)$ & $(0.060)$ & $(0.047)$ & $(0.060)$ \\
\hline \multirow[t]{2}{*}{ age } & 0.003 & 0.003 & 0.002 & 0.003 \\
\hline & $(0.004)$ & $(0.005)$ & $(0.004)$ & $(0.004)$ \\
\hline \multirow[t]{2}{*}{ payment } & 0.001 & 0.002 & 0.003 & 0.003 \\
\hline & $(0.001)$ & $(0.001)$ & $(0.001)$ & $(0.001)$ \\
\hline \multirow[t]{2}{*}{ businessdegree } & $0.150^{* * *}$ & $0.348^{* * *}$ & $0.171^{* * *}$ & $0.397 * * *$ \\
\hline & $(0.069)$ & $(0.092)$ & $(0.065)$ & $(0.087)$ \\
\hline lawdegree & $0.367 * * *$ & $0.324 * * *$ & $0.399 * * *$ & $0.467 * * *$ \\
\hline
\end{tabular}




\begin{tabular}{lllll} 
& $(0.088)$ & $(0.112)$ & $(0.084)$ & $(0.109)$ \\
accountingdegree & $0.420^{* * *}$ & $0.431^{* * *}$ & $0.413^{* * *}$ & $0.375^{* * *}$ \\
& $(0.148)$ & $(0.196)$ & $(0.142)$ & $(0.179)$ \\
_cons & $3.574^{* * *}$ & $3.456^{* * *}$ & $3.574^{* * *}$ & $3.368^{* * *}$ \\
& $(0.125)$ & $(0.151)$ & $(0.124)$ & $(0.152)$ \\
$\mathrm{N}$ & & & & \\
Deviance & 4133 & 3069 & 4070 & 3024 \\
aic & 11334 & 8862 & 11509 & 8974 \\
\hline
\end{tabular}

This table reports the results of MLE estimation of three-level random coefficients models excluding the year 2003 or 2004 for the preferred full model and firms that appointed more outside directors than the legal requirement (i.e., the 25 percent rule or the 50 percent rule). Figures in brackets are standard errors. *, **, *** refers to significance at 10, 5 and 1 percent level respectively. Random parts are not reported for brevity purpose. 
TABLE 8.

ESTIMATION RESULTS OF TWO-WAY RANDOM COMPONENT MODELS AND TWO-LEVEL RANDOM COEFFICIENT MODELS

\begin{tabular}{|c|c|c|c|c|c|c|}
\hline \multirow[b]{2}{*}{ Variable } & \multicolumn{4}{|c|}{ Non-hierarchical models } & \multicolumn{2}{|c|}{ Two-level models } \\
\hline & $\begin{array}{c}\text { Firm+ } \\
\text { year effect+ } \\
\text { committee } \\
\text { (1) }\end{array}$ & $\begin{array}{c}\text { Firm+ } \\
\text { year } \\
\text { effect+ } \\
\text { exceedingrate } \\
(2)\end{array}$ & $\begin{array}{c}\text { Firm effect+ } \\
\text { committee } \\
\text { (3) }\end{array}$ & $\begin{array}{c}\text { Firm effect+ } \\
\text { exceedingrate } \\
\text { (4) }\end{array}$ & $\begin{array}{l}\text { Full model with } \\
\text { committee } \\
(5)\end{array}$ & $\begin{array}{l}\text { Full model with } \\
\text { exceedingrate } \\
(6)\end{array}$ \\
\hline non-Korean & $\begin{array}{l}-3.204^{* * *} \\
(0.148)\end{array}$ & $\begin{array}{l}-3.851^{* * *} \\
(0.258)\end{array}$ & $\begin{array}{l}-3.202^{* * *} \\
(0.148)\end{array}$ & $\begin{array}{l}-3.849 * * * \\
(0.258)\end{array}$ & $\begin{array}{l}-2.075^{* * *} \\
(0.382)\end{array}$ & $\begin{array}{l}-2.608^{* * *} \\
(0.580)\end{array}$ \\
\hline committee & $\begin{array}{l}0.144 * \\
(0.101)\end{array}$ & & $\begin{array}{l}0.151^{*} \\
(0.101)\end{array}$ & & $\begin{array}{l}0.414^{* * *} \\
(0.066)\end{array}$ & \\
\hline $\begin{array}{l}\text { non-KoreanX } \\
\text { commitee }\end{array}$ & $\begin{array}{l}2.354^{* * *} \\
(0.230)\end{array}$ & & $\begin{array}{l}2.354 * * * \\
(0.230)\end{array}$ & & $\begin{array}{l}1.213 * * * \\
(0.420)\end{array}$ & \\
\hline exceedingrate & & $\begin{array}{l}0.624^{* *} \\
(0.278)\end{array}$ & & $\begin{array}{l}0.599 * * \\
(0.275)\end{array}$ & & $\begin{array}{l}1.847^{* * *} \\
(0.244)\end{array}$ \\
\hline $\begin{array}{l}\text { non-Korean } \\
\text { exceedingrate }\end{array}$ & & $\begin{array}{l}2.986^{* *} \\
(1.424)\end{array}$ & & $\begin{array}{l}2.985^{* *} \\
(1.425)\end{array}$ & & $\begin{array}{l}2.484^{*} \\
(1.489)\end{array}$ \\
\hline reappointment & $\begin{array}{l}0.194 * * * \\
(0.039)\end{array}$ & $\begin{array}{l}0.254^{* * *} \\
(0.051)\end{array}$ & $\begin{array}{l}0.190^{* * *} \\
(0.039)\end{array}$ & $\begin{array}{l}0.254^{* * *} \\
(0.050)\end{array}$ & $\begin{array}{l}0.199 * * * \\
(0.055)\end{array}$ & $\begin{array}{l}0.304^{* * *} \\
(0.058)\end{array}$ \\
\hline lawyer_doctor & $\begin{array}{l}-0.143^{* *} \\
(0.071)\end{array}$ & $\begin{array}{l}-0.307 * * \\
(0.106)\end{array}$ & $\begin{array}{l}-0.143^{* *} \\
(0.071)\end{array}$ & $\begin{array}{l}-0.307 * * \\
(0.106)\end{array}$ & $\begin{array}{l}-0.162 * \\
(0.097)\end{array}$ & $\begin{array}{l}-0.238 * * \\
(0.111)\end{array}$ \\
\hline journalist & $\begin{array}{l}-0.773^{* * *} \\
(0.181)\end{array}$ & $\begin{array}{l}-0.955^{* * *} \\
(0.243)\end{array}$ & $\begin{array}{l}-0.776^{* * *} \\
(0.181)\end{array}$ & $\begin{array}{l}-0.955^{* * *} \\
(0.243)\end{array}$ & $\begin{array}{l}-0.677^{* * *} \\
(0.228)\end{array}$ & $\begin{array}{l}-0.708^{* * *} \\
(0.270)\end{array}$ \\
\hline education & $\begin{array}{l}-0.112^{* *} \\
(0.035)\end{array}$ & $\begin{array}{l}-0.146^{* * *} \\
(0.044)\end{array}$ & $\begin{array}{l}-0.110^{* * *} \\
(0.035)\end{array}$ & $\begin{array}{l}-0.147 * * * \\
(0.044)\end{array}$ & $\begin{array}{l}-0.084^{* *} \\
(0.040)\end{array}$ & $\begin{array}{l}-0.158^{* * *} \\
(0.043)\end{array}$ \\
\hline age & $\begin{array}{l}0.001 \\
(0.003)\end{array}$ & $\begin{array}{l}-0.001 \\
(0.003)\end{array}$ & $\begin{array}{l}0.001 \\
(0.003)\end{array}$ & $\begin{array}{l}-0.002 \\
(0.003)\end{array}$ & $\begin{array}{l}0.001 \\
(0.004)\end{array}$ & $\begin{array}{l}0.006 \\
(0.004)\end{array}$ \\
\hline payment & $\begin{array}{l}0.003^{* *} \\
(0.001)\end{array}$ & $\begin{array}{l}0.003^{*} \\
(0.002)\end{array}$ & $\begin{array}{l}0.003^{* *} \\
(0.001)\end{array}$ & $\begin{array}{l}0.003^{*} \\
(0.002)\end{array}$ & $\begin{array}{l}0.008^{* * *} \\
(0.001)\end{array}$ & $\begin{array}{l}0.008^{* * *} \\
(0.001)\end{array}$ \\
\hline businessdegree & $\begin{array}{l}0.062^{*} \\
(0.048)\end{array}$ & $\begin{array}{l}0.128^{* *} \\
(0.062)\end{array}$ & $\begin{array}{l}0.061^{*} \\
(0.048)\end{array}$ & $\begin{array}{l}0.126^{* *} \\
(0.062)\end{array}$ & $\begin{array}{l}0.267^{* * *} \\
(0.059)\end{array}$ & $\begin{array}{l}0.293^{* * *} \\
(0.064)\end{array}$ \\
\hline lawdegree & $\begin{array}{l}0.174 * * \\
(0.066)\end{array}$ & $\begin{array}{l}0.332 * * \\
(0.088)\end{array}$ & $\begin{array}{l}0.174 * * \\
(0.066)\end{array}$ & $\begin{array}{l}0.330^{* *} \\
(0.088)\end{array}$ & $\begin{array}{l}0.330^{* * *} \\
(0.083)\end{array}$ & $\begin{array}{l}0.410^{* * *} \\
(0.092)\end{array}$ \\
\hline accountdegree & $\begin{array}{l}0.426 * * * \\
(0.104)\end{array}$ & $\begin{array}{l}0.479 * * * \\
(0.130)\end{array}$ & $\begin{array}{l}0.426 * * * \\
(0.104)\end{array}$ & $\begin{array}{l}0.475^{* * *} \\
(0.130)\end{array}$ & $\begin{array}{l}0.157 * * * \\
(0.127)\end{array}$ & $\begin{array}{l}0.173 * * * \\
(0.132)\end{array}$ \\
\hline _cons & $\begin{array}{l}3.815^{* * *} \\
(0.101)\end{array}$ & $\begin{array}{l}3.720 * * * \\
(0.124)\end{array}$ & $\begin{array}{l}3.815^{* * *} \\
(0.100)\end{array}$ & $\begin{array}{l}3.726 * * * \\
(0.122)\end{array}$ & $\begin{array}{l}3.650 * * * \\
(0.102)\end{array}$ & $\begin{array}{l}3.563 * * * \\
(0.116)\end{array}$ \\
\hline $\mathrm{N}$ & 5180 & 3852 & 5180 & 3852 & 4070 & 3852 \\
\hline Deviance & 17203 & 13548 & 17203 & 13550 & 15111 & 14849 \\
\hline aic & 17235 & 13580 & 17233 & 13580 & 15145 & 14883 \\
\hline
\end{tabular}


This table reports the MLE estimations of non-hierarchical two-way error-component models (Columns 1-4): AttendanceRate $_{j t}=\mathbf{x}^{\prime} \boldsymbol{\beta}+v_{1 j}\left[+v_{2 t}\right]+\varepsilon_{i t}$, where $j$ and $t$ respectively denotes the firm and year; and two-level random coefficients models (Columns 5-6): AttendanceRate ${ }_{i j}=\mathbf{x}^{\prime} \boldsymbol{\beta}+v_{0 j}^{(L 2)}+v_{1 j}^{(L 2)}$ non-Korean $+\varepsilon_{i j}^{(L 1)}$. Models (1), (3), and (5) are for the preferred full model (Model 6 in TABLE V.), which includes committee and its interaction with nonKorean, and Models (2), (4), and (6) are this full model replacing this committee variable with exceedingrate. The exceedingrate variable denotes the voluntary portion of the ratio of outside directors to board members. Figures in brackets are standard errors. *,**,*** refers to significance at 10, 5 and 1 percent level respectively. Random parts are not reported for brevity purpose.

GRAPH 1.

REGRESSION LINE FOR ATTENDANCE RATE OF FOREIGN AND KOREAN
OUTSIDE DIRECTORS, PREDICTED BY INDEPENDENT APPOINTMENT
PROCESS

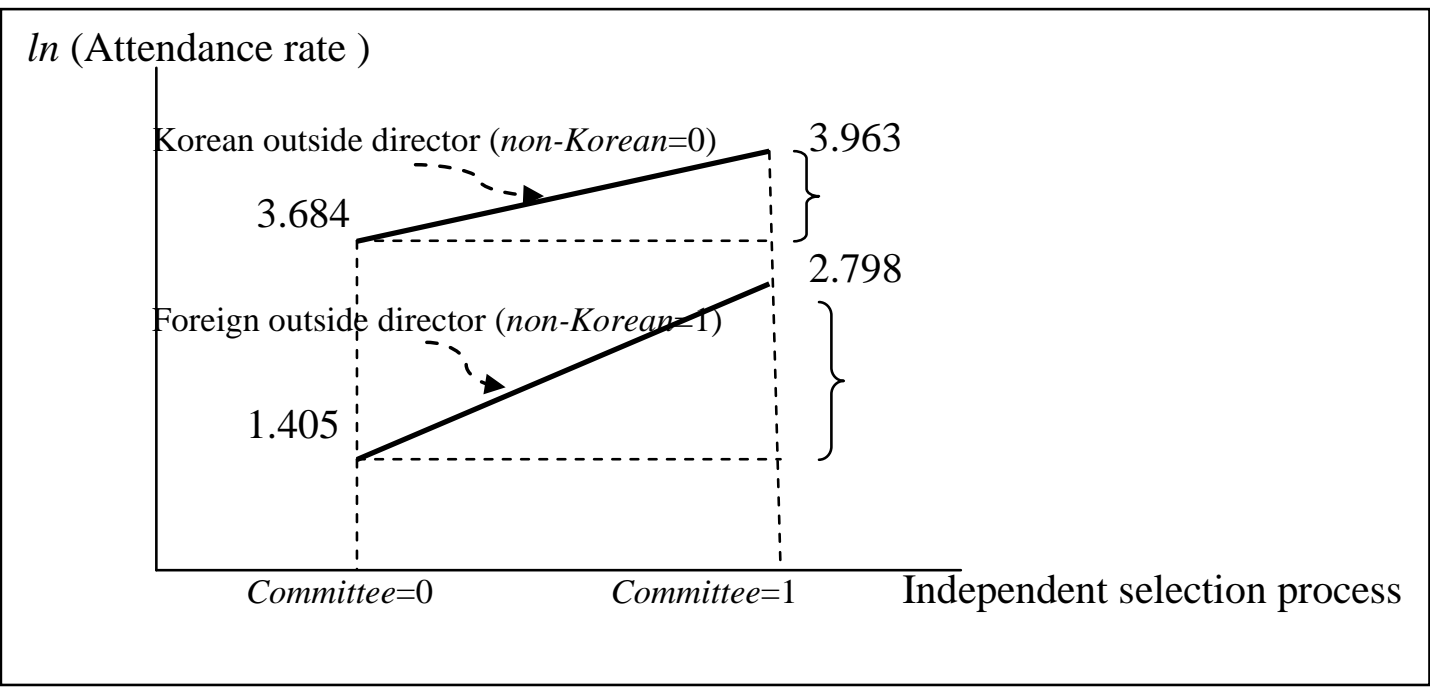

This graph reports the heterogeneous intermediate effect of an independent selection process for outside directors on the natural logarithm of attendance rate of Korean outside directors (non-Korean=0) in comparison with foreign outside directors (non-Korean=1). It depicts the regression line for the attendance rate of foreign outside directors, predicted by independent selection (i.e., committee $=1$ ) or lack of independent selection (i.e., committee $=0$ ). The prediction is based on

$\ln ($ Attendance Rate $)=3.684-2.228$ non - Korean +0.278 committee +1.106 non - Korean $\times$ committee. ${ }^{\circ}$

The two numbers on the left hand side (LHS) indicate average log attendance rate of foreign outside directors in a firm that appoints outside directors without committee screening (committee $=0$ ). The remaining two numbers on the RHS indicate the expected log attendance rate of Korean and foreign outside directors when a firm appoints outside directors through a committee screening process. 